\title{
Current phototherapy practice on Java, Indonesia
}

\author{
Mahendra T. A. Sampurna ${ }^{1 *}$ D, Kinanti A. Ratnasari ${ }^{1}$, Darto Saharso ${ }^{1}$, Arend F. Bos ${ }^{2}$, Pieter J. J. Sauer ${ }^{2}$, \\ Peter H. Dijk² and Christian V. Hulzebos ${ }^{2}$
}

\begin{abstract}
Background: In Indonesia, the burden of severe hyperbilirubinemia is higher compared to other countries. Whether this is related to ineffective phototherapy (PT) is unknown. The aim of this study is to investigate the performance of phototherapy devices in hospitals on Java, Indonesia.

Methods: In 17 hospitals we measured 77 combinations of 20 different phototherapy devices, with and without curtains drawn around the incubator/crib. With a model to mimic the silhouette of an infant, we measured the irradiance levels with an Ohmeda BiliBlanket Meter II, recorded the distance between device and model, and compared these to manufacturers' specifications.

Results: In nine hospitals the irradiance levels were less than required for standard PT: $<10 \mu \mathrm{W} / \mathrm{cm}^{2} / \mathrm{nm}$ and in eight hospitals irradiance failed to reach the levels for intensive phototherapy: $30 \mu \mathrm{W} / \mathrm{cm}^{2} / \mathrm{nm}$. Three hospitals provided very high irradiance levels: $>50 \mu \mathrm{W} / \mathrm{cm}^{2} / \mathrm{nm}$. Half of the distances between device and model were greater than recommended. Distance was inversely correlated with irradiance levels $\left(R^{2}=0.1838 ; P<0.05\right)$. The effect of curtains on irradiance levels was highly variable, ranging from -6.15 to $+15.4 \mu \mathrm{W} / \mathrm{cm} 2 / \mathrm{nm}$, with a mean difference (SD) of $1.82(3.81) \mu \mathrm{W} / \mathrm{cm} 2 / \mathrm{nm}(P=0.486)$.

Conclusions: In half of the hospitals that we studied on Java the levels of irradiance are too low and, in some cases, too high. Given the risks of insufficient phototherapy or adverse effects, we recommend that manufacturers provide radiometers so hospitals can optimize the performance of their phototherapy devices.
\end{abstract}

Keywords: Curtain, Distance, Hyperbilirubinemia, Irradiance, Phototherapy

\section{Key notes}

- Inappropriate phototherapy may contribute to the high burden of severe hyperbilirubinemia in Indonesia: increase the risk of bilirubin encephalopathy as well as the number of exchange transfusions.

- In half of the hospitals that we studied irradiance levels were too low, while in some the levels were very high.

- Half the distances between device and model were greater than recommended.

\footnotetext{
* Correspondence: mahendra.tri@fk.unair.ac.id

${ }^{1}$ Department of Pediatrics, Dr. Soetomo General Hospital, Faculty of Medicine Universitas Airlangga, Surabaya, Indonesia

Full list of author information is available at the end of the article
}

\section{Background}

Worldwide, hyperbilirubinemia contributes 40 to $60 \%$ of neonatal hospital admissions [1]. Untreated hyperbilirubinemia may cause neurotoxicity that ultimately results in one of the kernicterus spectrum disorders [2]. A recent survey in Indonesia indicated a $7 \%$ incidence of hyperbilirubinemia, defined as a serum bilirubin level of $>340 \mu \mathrm{mol} / \mathrm{L}(20 \mathrm{mg} / \mathrm{dL})$, in all newborn infants [3]. Acute bilirubin toxicity was found in $2 \%$ of newborn infants admitted [3]. Why the incidence and burden of hyperbilirubinemia is much higher in Indonesia compared to other countries is unknown.

Phototherapy (PT) has proven to be effective in reducing levels of unconjugated bilirubin. Worldwide there are many different guidelines indicating when to start and when to stop administering PT [4-6]. Studies have shown that PT can reduce total serum bilirubin (TSB) levels and

(c) The Author(s). 2019 Open Access This article is distributed under the terms of the Creative Commons Attribution 4.0 International License (http://creativecommons.org/licenses/by/4.0/), which permits unrestricted use, distribution, and reproduction in any medium, provided you give appropriate credit to the original author(s) and the source, provide a link to the Creative Commons license, and indicate if changes were made. The Creative Commons Public Domain Dedication waiver (http://creativecommons.org/publicdomain/zero/1.0/) applies to the data made available in this article, unless otherwise stated. 
thus prevent neurotoxicity and kernicterus spectrum disorders $[7,8]$. For it to be effective, however, PT requires a specific level of irradiance. Studies carried out in both high-income and low-and-middle-income countries reported considerable variance in the irradiance levels of the PT devices used [9-11]. In a number of devices irradiance levels were suboptimal or insufficient, possibly causing ineffective treatment, while aggressive PT and too high levels of irradiance may be dangerous and associated with adverse effects $[12,13]$.

The irradiance levels of PT also depend on the distance between the PT device and the infant. All guidelines and manufacturers' information provide recommendations concerning optimal and safe distances, but it is not clear how critical the effect of the actual distance is on irradiance levels. General practice in Indonesia is to cover the incubators or cribs with curtains when PT is administered. This is done to protect other infants in the room against the light and to increase the irradiance of the PT by reflection. Using reflective curtains may reduce TSB levels more rapidly than not using reflective curtains [5]. It is unknown, however, whether non-reflective curtains will also increase the effectiveness of PT. The aim of this study was to investigate the irradiance levels of PT in clinical practice in Indonesia. In addition, we analyzed the effect of distance between the PT device and the infant, and the effect of curtains on irradiance levels.

\section{Methods}

Between December 2016 and August 2017 we visited 17 hospitals with Level II and Level III neonatal intensive care units (NICUs) on Java, Indonesia to measure the irradiance levels of PT devices. We had intended to study overhead as well as underneath PT devices in a clinical setting, but because we found only one underneath PT device, which was no longer in use anyway, we excluded underneath PT devices. Local NICU nurses placed a model of the silhouette of a preterm infant once in the incubator or crib and installed the overhead PT device as they would in daily practice. We had marked the model with five measurement points at 3, 12, 18, 23, and $33 \mathrm{~cm}$ apart, to represent an infant's head, trunk, abdomen, knees, and feet [9]. If a device had more than one irradiation mode we measured the highest irradiance level of that PT device. The second series of irradiance measurements were done once using curtains if this was routine practice in that specific hospital. The nurses drew the curtain around the incubator or crib as they would do in everyday practice. Irradiance levels were measured in exactly the same way as without the curtains.

We measured irradiance using a new Ohmeda BiliBlanket Meter II (Konica Minolta Inc., Tokyo, Japan) that had been calibrated before use by the manufacturer. According to the specifications of the manufacturer, only one calibration per year is needed. All our measurements were done within the year of the calibration. This radiometer is designed to measure light radiation with a bandwidth range of 400 to $520 \mathrm{~nm}$ and peak sensitivity at 450 $\mathrm{nm}$. The measuring range of the spectral irradiance is from 0.1 to $299.9 \mu \mathrm{w} / \mathrm{cm}^{2} / \mathrm{nm}$. Standard PT was defined as PT with irradiance levels between 10 and $30 \mu \mathrm{w} / \mathrm{cm}^{2} / \mathrm{nm}$. If irradiance levels were above $30 \mu \mathrm{w} / \mathrm{cm}^{2} / \mathrm{nm}$, PT was defined as intensive PT [4].

For each PT device we used the mean values of the five replications for further calculations. Per device the means of all measurement points were averaged to one mean intensity level, in agreement with the definition of the effective surface area by the International Electrotechnical Commission and in agreement with the AAP recommendations [4].

To evaluate the effect of distance on irradiance level, we measured the distance in $\mathrm{cm}$ between the PT device and silhouette model at the measurement point closest to the PT device. One silhouette was used for all measurements. It is a two dimensional model with a brown color. We searched for specifications of the phototherapy devices and recommendations of the manufacturers by searching the internet using the names of the devices and the official websites of the manufacturers.

The study was approved by the Ethical Committee in Health Research of the Dr. Soetomo General Hospital Surabaya (number 390/Panke.KKE/V/2017). The need to ask Ethical approval and the need to ask consent from parents was waived by our Ethical Committee because no human subjects were involved in this study.

\section{Data and statistical analysis}

We used SPSS for Windows, Version 21 (IBM., Corp,. Armonk, N.Y., USA) for data analysis. First, we calculated the medians and ranges of the irradiance levels for each device. Five measurements were done for each point of the silhouette. The mean of the five measurements was calculated. Next, the mean and range of the five means was used for the analysis of the total irradiance. Second, we plotted the mean irradiance levels of the PT devices of each hospital in a graph. Third, we analysed the relationship of the irradiance levels with the distance between the PT device and the model using linear regression analysis. We compared the measured irradiance levels and the distances with those stated in the manufacturers' specifications by using independent sample $\mathrm{T}$ tests, and we constructed Bland-Altman graphs to analyse the differences between irradiance levels per device, with and without curtains, one for irradiance levels below $30 \mu \mathrm{w} / \mathrm{cm}^{2} / \mathrm{nm}$ and one for above $30 \mu \mathrm{w} / \mathrm{cm}^{2} / \mathrm{nm}$. We arbitrarily chose this irradiance level to analyse whether the effect of curtains on irradiance levels depended on standard and intensive PT. We used the Mann-Whitney 
test to analyse the differences between irradiance levels measured with and without curtains. A $P$ value below 0.05 was considered statistically significant.

\section{Results}

We measured 77 PT devices of 20 different types in the 17 hospitals we visited. The irradiance levels of all types of devices included in this study are given in Table 1 . Most types of devices used fluorescent light sources, six used light-emitting diodes (LEDs), and one used halogen. The irradiance levels of the PT devices varied widely. In three PT devices all the irradiance levels were below $10 \mu \mathrm{W} / \mathrm{cm}^{2} / \mathrm{nm}$ and in six devices the median levels were below $10 \mu \mathrm{W} / \mathrm{cm}^{2} / \mathrm{nm}$. Eleven out of $20 \mathrm{PT}$ devices had a manufacturer's manual that contained detailed information on how to use the device and what irradiance levels the device should produce [14-24]. For the other nine devices we could not find detailed manufacturers' specifications. Two out of 11 PT devices provided irradiance levels well below ( $12 \%$ or less) the given manufacturers' specification. Six of the nine other devices with manufacturers' specifications produced irradiance levels below the lower range of intensity recommended in the manufacturers' specifications.

Regarding the hospitals, we found a wide variation in the irradiance levels, both between and within hospitals. Figure 1 shows the mean irradiance levels of all PT devices in all hospitals. The irradiance levels ranged from 0.68 to $127 \mu \mathrm{W} / \mathrm{cm}^{2} / \mathrm{nm}$. Nine (53\%) of the hospitals used PT devices with an intensity below the standard PT of $10 \mu \mathrm{W} / \mathrm{cm}^{2} / \mathrm{nm}$. Eight (47\%) of the hospitals did not have PT devices that produced an intensity of at least $30 \mu \mathrm{W} / \mathrm{cm}^{2} / \mathrm{nm}$, the level required for intensive PT. Three hospitals used PT devices with irradiance levels above $50 \mu \mathrm{W} / \mathrm{cm}^{2} / \mathrm{nm}$. These were mostly LED-based PT devices. The irradiance level of one LED device was too low.

The distance between the model and PT devices ranged from 17 to $59 \mathrm{~cm}$ (mean \pm SD: $37.8 \pm 8.3 \mathrm{~cm}$ ), while the manufacturers recommended distances ranging from 20 to $40 \mathrm{~cm}$ (mean \pm SD: $31.9 \pm 6.3 \mathrm{~cm}$ ) that, with a difference of $5.9 \mathrm{~cm}$, is significantly closer $(P<0.026)$. Table 1 also provides the distance between the PT devices and the infant as recommended by the manufacturers and the

Table 1 Phototherapy devices per hospital, range of irradiance levels, and distances measured and recommended by the manufacturers

\begin{tabular}{|c|c|c|c|c|c|}
\hline \multirow[t]{2}{*}{ PT devices } & \multirow{2}{*}{$\begin{array}{l}\text { No. of } \\
\text { hospitals /devices } \\
(\mathrm{n} / \mathrm{n})\end{array}$} & \multicolumn{2}{|l|}{$\begin{array}{l}\text { Irradiance levels } \\
\left(\mu \mathrm{W} / \mathrm{cm}^{2} / \mathrm{nm}\right)\end{array}$} & \multicolumn{2}{|l|}{$\begin{array}{l}\text { Distance } \\
(\mathrm{cm})\end{array}$} \\
\hline & & $\begin{array}{l}\text { Measured } \\
\text { median (range) }\end{array}$ & $\begin{array}{l}\text { Specified by MDA } \\
\text { Manufacturer }^{\mathrm{a}}\end{array}$ & $\begin{array}{l}\text { Measured } \\
\text { median (range) }\end{array}$ & Recommended \\
\hline Airshield Foto Tx System ${ }^{b}$ & $1 / 1$ & $0.7(0.5-0.9)$ & - & 40 & - \\
\hline Fanem Bilitron $3006^{c}[14]$ & $1 / 1$ & $2.6(0.7-3.6)$ & $35-40$ & 40 & 30 \\
\hline Tesena $^{\mathrm{b}}[15]$ & $1 / 1$ & $7.3(5.4-7.7)$ & 62 & 24 & 30 \\
\hline Choongwae $\mathrm{PT}^{\mathrm{b}}$ & $1 / 2$ & $7.9(5.5-10.3)$ & - & $41(37-45)$ & - \\
\hline Gammatech PT BGM ${ }^{b}$ & $1 / 4$ & $8.3(7-10.1)$ & - & 50 & - \\
\hline My Life MP-71 ${ }^{b}$ & $4 / 5$ & $8.6(6-15.5)$ & - & $40(40-45)$ & 30 \\
\hline GEA XHZ 90 [16] & $7 / 18$ & $11.3(6.6-39.4)$ & $9-27$ & $40(25-59)$ & - \\
\hline Nidea PT 2000-1600 & $1 / 2$ & $11.7(7.1-16.1)$ & - & 30 & - \\
\hline Medela ${ }^{\mathrm{b}}[17]$ & $4 / 12$ & $13.3(3.5-38.5)$ & $14-31$ & $30(28-40)$ & $25-40$ \\
\hline YON DON PT & $1 / 2$ & $13.7(9.1-19.7)$ & - & 40 & - \\
\hline Onemed GLQ $2^{b}$ & $1 / 1$ & $14.7(13-15.7)$ & - & 40 & - \\
\hline $\begin{array}{l}\text { Ohmeda } 2 \text { pcs PT Light II } \\
\text { Halogen + Philips Blue }{ }^{d} \text { [18] }\end{array}$ & $1 / 1$ & $15.9(8.4-27.8)$ & $3-76$ & $(15-35)$ & 40 \\
\hline Draeger PT 4000 [19] & $2 / 3$ & $19.1(9.7-35)$ & $14-27$ & $32.5(30-35)$ & $30-40$ \\
\hline GE Lullaby Fluoresens ${ }^{\mathrm{b}}[20]$ & $1 / 2$ & $23.3(13.1-25)$ & $20-30$ & 35 & 30 \\
\hline Philips TL 20 W/52 SLV/25 & $3 / 5$ & $30.9(9.1-36.8)$ & - & $35(29-37)$ & - \\
\hline Bistos BT $400^{c}[21]$ & $2 / 3$ & $32.7(11.9-79.3)$ & $>30$ & $42(34-50)$ & 30 \\
\hline GE Lullaby LED [22] & $4 / 9$ & $39.9(12.5-57.9)$ & $22-45$ & $40(32-45)$ & 30 \\
\hline Tende LED ${ }^{\complement}[23]$ & $2 / 2$ & $46(36.5-127)$ & $33-120$ & $32.5(30-35)$ & 40 \\
\hline Seefar 4000 Spot $^{c}$ & $1 / 2$ & $65.2(44.4-80.6)$ & - & 25 & - \\
\hline Novos Bilisphere LED ${ }^{C}[24]$ & $1 / 1$ & $91.4(65.3-95.7)$ & $>60$ & 17 & 20 \\
\hline
\end{tabular}

${ }^{a}$ Data provided by the Medical Device Agency (MDA) or Manufacturers in $\mu \mathrm{W} / \mathrm{cm}^{2} / \mathrm{nm}$, the lowest and highest value are presented [14-24] Type of PT device: ${ }^{b}$ Fluorescent, ' ${ }^{C L D}$, ${ }^{d}$ Halogen 


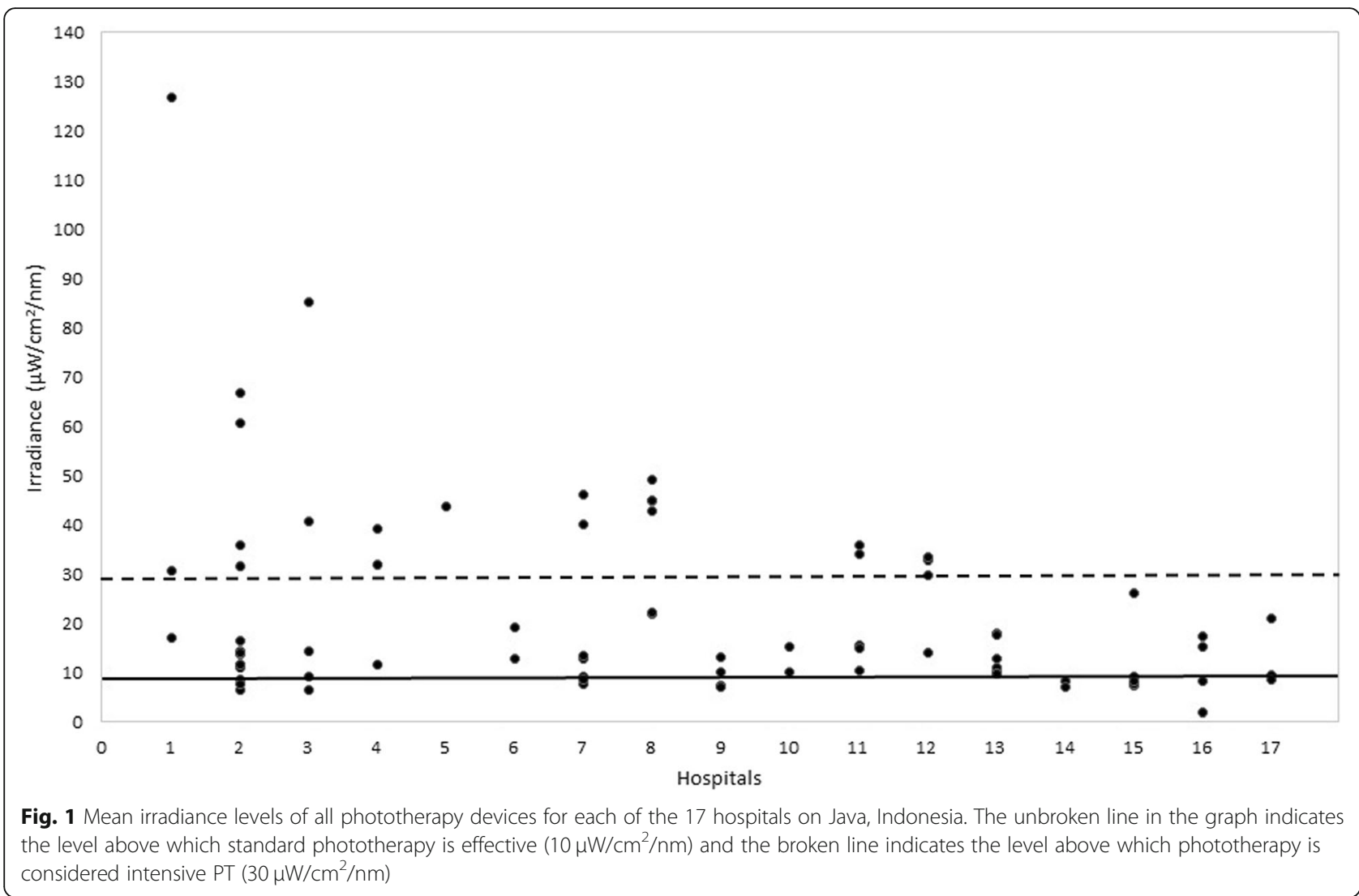

distance used in daily practice. We found one half (20 out of 40) of the distances between device and model to be greater than the distance recommended by the manufacturers. As we show in Fig. 2, there was a significant inverse relationship between the distance of the PT device to the model and the irradiance levels, $\left(R^{2}=0.1838 ; P<0.05\right)$. With every $1 \mathrm{~cm}$ increase in distance, intensity decreased by approximately $1.1 \mu \mathrm{W} / \mathrm{cm}^{2} / \mathrm{nm}$. Thus, the mean difference between the measured and recommended distance of $5.9 \mathrm{~cm}$ accounts for a mean reduction in intensity of 5.9 times 1.0777 equals $6.4 \mu \mathrm{W} / \mathrm{cm}^{2} / \mathrm{nm}$.

One hospital did not use curtains, eight hospitals used white curtains, and one hospital used black curtains, the remaining seven hospitals used a variety of mostly lightcoloured curtains. The difference in irradiance levels, with and without curtains, was highly variable and ranged from -6.15 and $+15.4 \mu \mathrm{W} / \mathrm{cm} 2 / \mathrm{nm}$ per measurement point, with a mean difference (SD) of $1.82(3.81) \mu \mathrm{W} / \mathrm{cm} 2 / \mathrm{nm}$, and the overall effect was not significant $(P=0.486)$. In Fig. 3 we present the difference in irradiation levels per device, with and without curtains, for standard PT with irradiance levels below $30 \mu \mathrm{W} / \mathrm{cm}^{2} / \mathrm{nm}$, and in Fig. 4 for intensive PT with irradiance levels above $30 \mu \mathrm{W} / \mathrm{cm}^{2} / \mathrm{nm}$. For irradiance levels below $30 \mu \mathrm{W} / \mathrm{cm}^{2} / \mathrm{nm}$, the mean (SD) difference was $1.05(2.08) \mu \mathrm{W} / \mathrm{cm}^{2} / \mathrm{nm}$ higher with curtains $(P=0.370)$. Above $30 \mu \mathrm{W} / \mathrm{cm}^{2} / \mathrm{nm}$, the mean (SD) difference for irradiation levels was 2.58 (4.37) $\mu \mathrm{W} / \mathrm{cm}^{2} / \mathrm{nm}$ higher with curtains, but it also failed to reach statistical significance $(P=0.572)$. The raw data of PT irradiance from all hospital is provided in Additional file 1.

\section{Discussion}

In this observational study we found that the intensity of phototherapy varied considerably both within and between hospitals on Java, in Indonesia. Devices with irradiance levels below which PT is recommended were in use in more than half of the hospitals. Moreover, nearly half of the hospitals did not have devices that provided sufficient irradiance for intensive PT. By contrast, some hospitals had PT devices that produced very high irradiance levels that perhaps enhanced the efficacy of PT [25, 26], but were perhaps not always safe $[12,13]$. Altogether, the effect of PT on hyperbilirubinemia may be highly unpredictable.

The irradiance levels of the PT devices varied considerably, with a high percentage of ineffective standard and intensive PT. This finding was in line with other studies performed in either developed or developing countries [9-11]. According to Bhutani and colleagues, there are four different explanations for low irradiance levels of PT in developing countries [27]. First, the sources of light may be inferior. Second, maintenance 


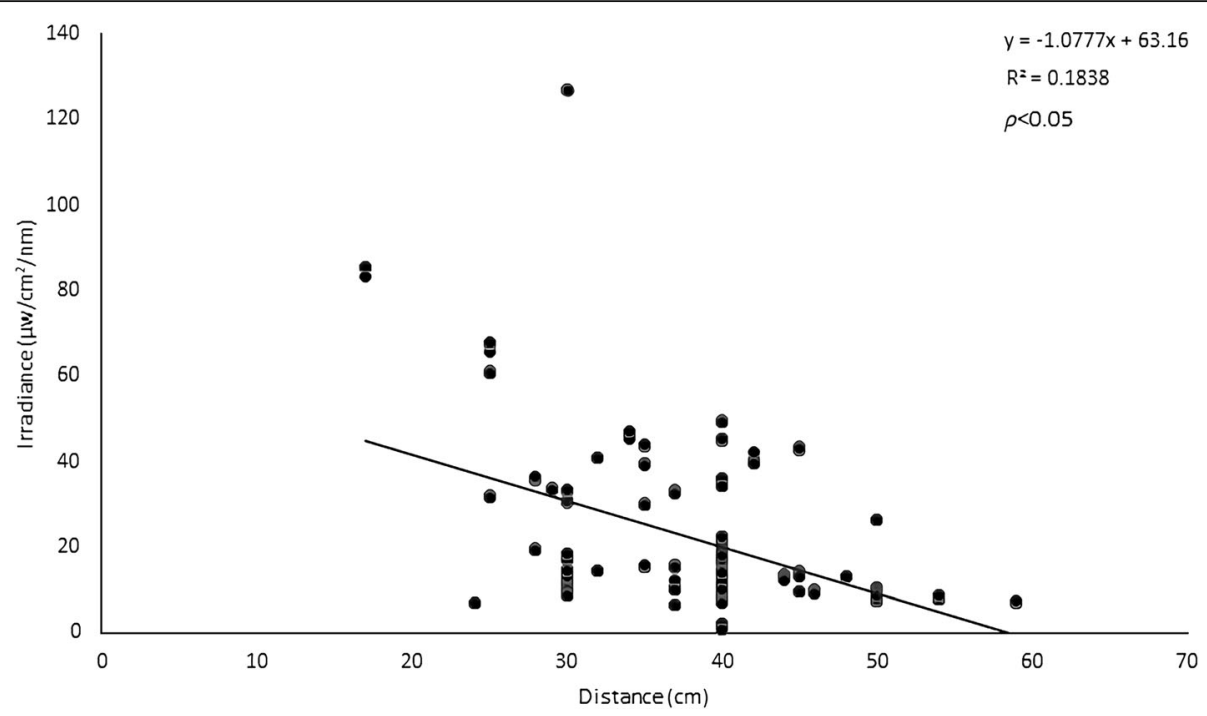

Fig. 2 The relationship between the distance of the phototherapy device and the model and the mean irradiance levels of each device, measured without curtains. For the irradiance levels we calculated the mean of the measurements of the five points marked on the model (see Methods). The line in the graph represents the regression line, the concomitant formula is presented in the upper right-hand corner of the graph

constraints may play a role. Third, countries may lack a steady supply of electrical power. Lastly, awareness of the requirements for effective phototherapy may be lacking, such as the importance of the distance between the infant and the PT device.
The most likely explanations for the low levels of irradiance found on Java are inferior PT devices, lack of awareness of the requirements for effective PT, insufficient maintenance, and too great a distance between the infant and the PT device. Increasing awareness of the

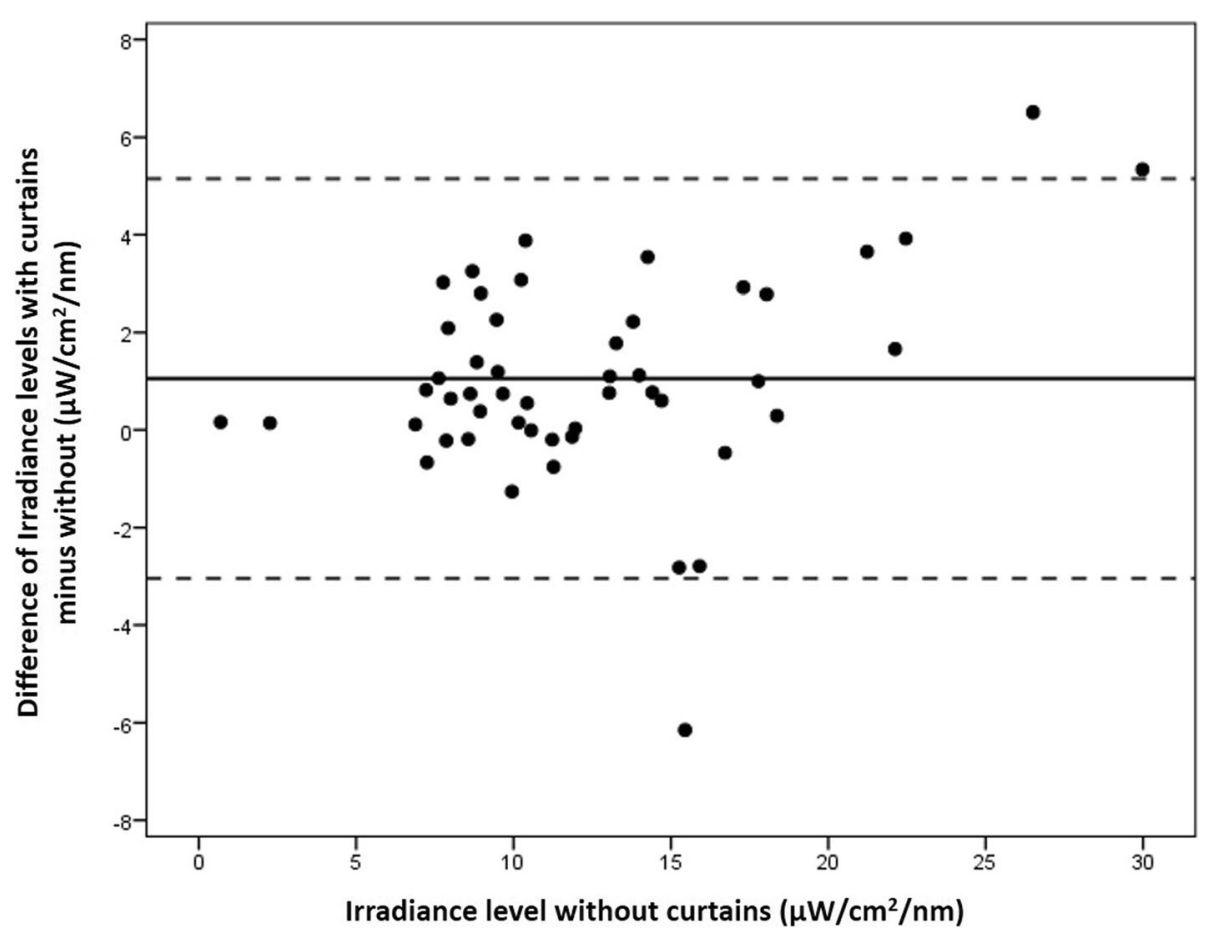

Fig. 3 Bland-Altman plot showing the difference of irradiance levels of each phototherapy device, with curtains compared to without curtains, for those phototherapy devices that had irradiance levels below $30 \mu \mathrm{w} / \mathrm{cm}^{2} / \mathrm{nm}$. Each phototherapy device presents one dot, the mean (SD) difference was $1.05(2.08) \mu \mathrm{W} / \mathrm{cm}^{2} / \mathrm{nm}$ higher when using curtains $(P=0.370)$ 


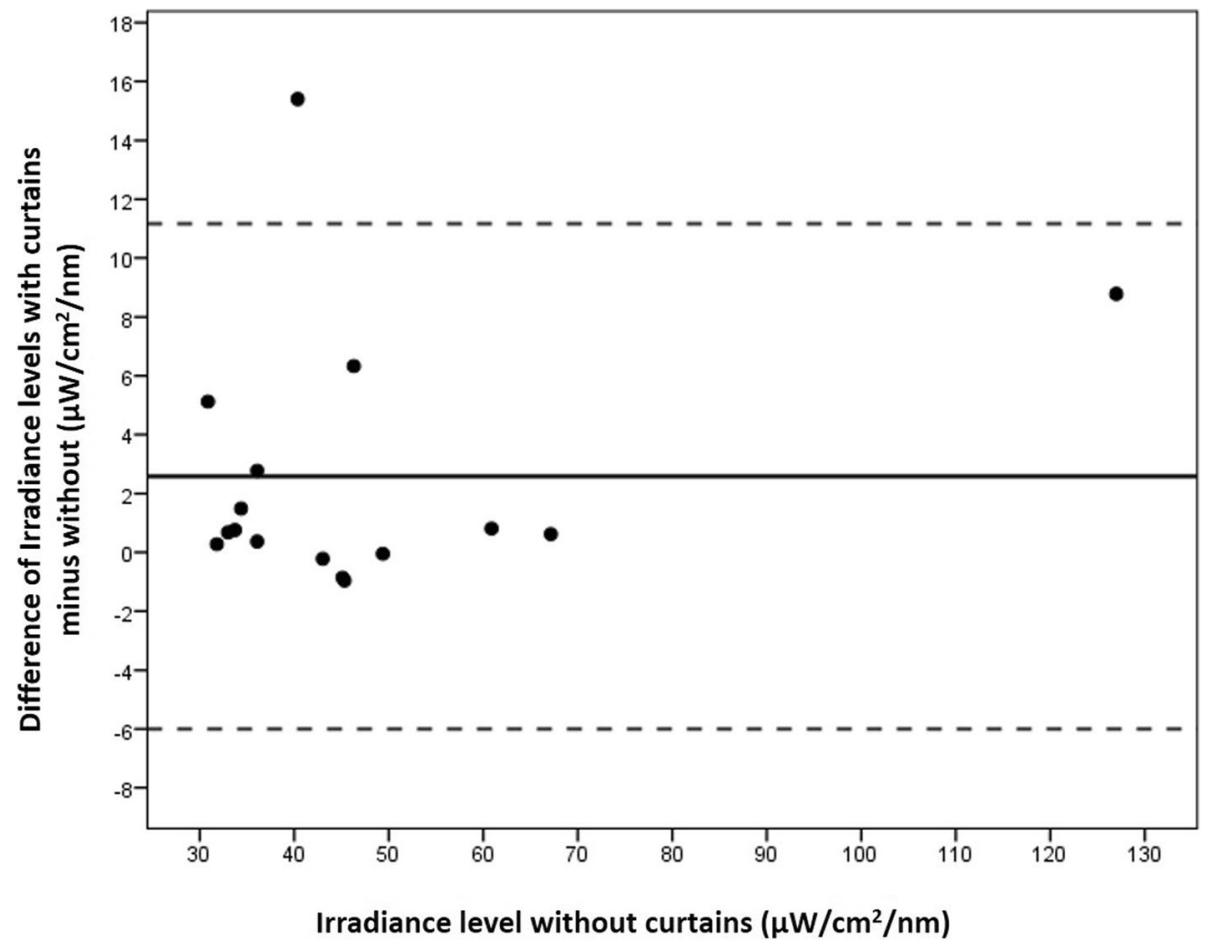

Fig. 4 Bland-Altman plot showing the difference of irradiance levels of phototherapy with curtains compared to without curtains, for phototherapy devices that have irradiance levels above $30 \mu \mathrm{w} / \mathrm{cm}^{2} / \mathrm{nm}$. Each phototherapy device presents one dot. The mean (SD) difference was $2.58(4.37) \mu \mathrm{W} / \mathrm{cm}^{2} / \mathrm{nm}$ higher when using curtains $(P=0.572)$

factors that affect PT efficacy will undoubtedly result in better performance of the devices and smaller distances [28]. The AAP recommends measuring the intensity of PT devices regularly [4]. On Java, however, none of the hospitals we visited had a radiometer to measure irradiance. Neither did any of the companies that supplied the PT devices to the hospitals also provide radiometers. We do not know whether this is due to a lack of awareness on the part of the suppliers of PT devices or on the part of those who purchase PT devices, or whether other constraints play a role. Furthermore, it is common knowledge that irradiance levels of conventional lamps and tubes decrease with use. These lamps and tubes should therefore be checked periodically and replaced if necessary. In most hospitals on Java, however, it is not customary to replace PT lamps that still seem to be working properly. On the other hand, it is not possible to check whether a PT device is functioning properly without a radiometer. Our results are in line with data from Nigeria, where routine irradiance monitoring is also uncommon, whereas periodically monitoring of irradiance is recommended [29,30].

The majority of PT devices with low irradiance were fluorescent tube-based devices, but there was one LEDbased PT device that had low irradiance. Olusanya and colleagues found that irradiance decay was higher and occurred faster in fluorescent tube-based PT devices compared to LED-based PT devices [29]. LED-based PT devices also show irradiance decay, but after a much longer period of use. LED-based PT devices may last up to $20,000 \mathrm{~h}$ while fluorescent tube-based PT devices may require lamp replacement every $3000 \mathrm{~h}$ [27]. Therefore, LED-based PT should be preferred in resourceconstrained settings. Nevertheless, regular irradiance monitoring is always essential, also in resource-constrained settings $[4,30]$.

Only for 11 of the 20 devices used, did we find the manufacturers' specifications. This is odd, because without these specifications healthcare workers cannot be expected to know the performance of the device, the recommendations for effective use and, even more essential, the safety precautions. On Java, all hospitals have sufficient electrical power supplies, so the third explanation of Bhutani and colleagues [27] does not apply. Finally, we often found that the distances between the model and the PT device, as installed by the nurses according to their routine clinical practices, were too great and often not in accordance with the manufacturers' recommendations. Significant improvements in irradiance could be gained if all parties involved in selling, buying, and using PT devices were better informed about the principles of effective PT. 
In a few instances, we also found very high irradiance levels - up to $127 \mu \mathrm{W} / \mathrm{cm}^{2} / \mathrm{nm}$. This was the case in specific devices that delivered PT to the infant in 360 degrees and in some overhead PT devices using blue light LEDs. Levels above $50 \mu \mathrm{W} / \mathrm{cm}^{2} / \mathrm{nm}$ are more effective in decreasing TSB levels faster $[25,26]$. Nevertheless, several studies reported that intensive phototherapy may cause deoxyribonucleic acid (DNA) damage and increased apoptosis [31-33]. One epidemiologic study reported that infants with a history of phototherapy the risk of cancer is up to two times higher than in non-exposed infants, albeit a very low absolute risk [34]. Other studies reported a tendency towards increased mortality, especially in extremely low birth weight infants, which was not related to PT intensity, but to the duration of PT $[12,13]$. To prevent potential adverse effects it is logical to limit the duration of PT. In addition, an effective but short period of PT will interfere less with parent- child interaction.

We found no overall significant effect on irradiance levels in the case of curtains drawn around the incubator or crib. In most hospitals on Java, curtains are used around cribs with a PT device to protect other infants against the light and to increase the irradiance level of PT devices by reflection at the same time. Eggert and colleagues suggested lining the incubator with reflective cloth to increase the radiant power of PT devices [35]. This study was supported by studies in Germany, India, and Malaysia that reported that a white curtain around the PT device may reduce TSB faster, without reducing the total time of administering PT [36-38]. The National Institute for Health and Care Excellence (NICE) guideline does not recommend using curtains because it prevents observing the baby [5]. As most of the curtains used in our study were light-coloured (but not white and possible not reflective), we believe that this may be the explanation for the unpredictable effect we found. In fact, this observation underlines the need to measure irradiance. A reason for the rather wide variation between the measurements with and without curtains might be that we studied curtains made of different materials and with different colors. Another study is needed to evaluate effects of different reflective materials and of different colors on irradiance.

Indonesia has not yet a national guideline on the management of hyperbilirubinemia and no specific recommendation for phototherapy. Pediatricians in Indonesia are advised to use the AAP guidelines for the treatment of hyperbilirubinemia. Previously, we found that only $54 \%$ of pediatricians in Indonesia follow these guidelines [39]. We think that a national guideline should contain recommendations and information about phototherapy that supports a better awareness of the requirements for effective phototherapy.
Our study has some limitations. First, we included only 17 hospitals on Java. This limits the generalizability of our findings, because these 17 hospitals may not be representative of the whole of Indonesia. We suspect that other hospitals in other parts of the country are perhaps less well-equipped. Our results could therefore be an overestimation of the effectiveness of PT devices for the whole country. Second, we used a single radiometer. The values we found might have been different had we used device-specific radiometers [40]. The advantage of the radiometer we used is that it covered a wide range of wavelengths. Third, the model we used is not a real infant. Nevertheless, we believe that the model approximated irradiance levels quite well because we measured at five points. Fourth, some of the PT devices in the hospitals had been in use for quite some time. We were not able to retrieve the manufacturer's information and specifications for nine of the 20 devices.

Our findings may have implications for clinical practice. We recommend measuring the irradiance levels of all PT devices in all hospitals in order to provide effective standard and intensive PT. Manufacturers should provide essential information about the performance and safety of their devices, in addition they should provide radiometers to measure irradiance levels, and the hospitals should buy them and use them. Significant improvements in irradiance would be gained if all who sell, buy, and use PT devices were better informed about the principles of effective PT.

\section{Conclusion}

Half of the hospitals that we studied on Java, Indonesia, use PT devices that provide PT levels that are too low, while some provide very high levels of PT. Given the risks of either insufficient PT or adverse effects, we recommend that manufacturers provide radiometers and that heath care providers measure irradiance to optimize the performance of their PT devices so as to reduce the burden of severe hyperbilirubinemia in Indonesia.

\section{Additional file}

Additional file 1: Intensity data of all phototherapy devices from participating hospitals. (XLSX 86 kb)

Abbreviations

AAP: American Academy of Pediatrics; LED: Light-emitting diode; NICE: The National Institute for Health and Care Excellence; NICU: Neonatal intensive care units; PT: Phototherapy; TSB: Total serum bilirubin

\section{Acknowledgements}

We acknowledge the help of Titia van Wulfften Palthe, PhD, for editing the English manuscript. We appreciate the help of many doctors who helped with data collection, including in:

Surabaya: Robby Nurhariansyah (Airlangga University Hospital); Dina Angelika (Dr. Soetomo General Hospital); Dina Djojohusodo (RKZ Hospital); Diana Amilia Susilo (Kendangsari Hospital); Agus Cahyono (BDH Hospital); Kartika 
Darma Handayani (Kendangsari Merr Hospital); Irwanto (Husada Utama Hospital); Risa Etika (Putri Women \& Children Hospital); Roedi Irawan (NUN Women \& Children Hospital); Agus Harianto (Premier Hospital); Martono Tri Utomo (Dr. Soemitro Hospital); Reza Gunadi Ranuh (Lombok 22 Hospital); Dian Pratamastuti (Siloam Hospital); Satrio Boediman (IBI Hospital). Jakarta: Setyadewi Lusyati (Harapan Kita Women \& Children Hospital). Bandung: Aris Primadi \& Tetty Yuniati (Hasan Sadikin General Hospital). Malang: Eko Sulistijono (Saiful Anwar General Hospital).

\section{Authors' contributions}

MTAS participated in designing the study, collected the data for all hospitals, assisted in data analysis and interpretation, and wrote the first draft of the manuscript. KAR helped with data analysis and made the figures and tables. DS helped with literature search and revised the manuscript. AFB and PJJS contributed to the data analyses and interpretation. PJJS also helped to write and revise the manuscript and assisted to design this study. AFB read and revised the manuscript. PHD and $\mathrm{CVH}$ helped to design the study, especially the methodology and the interpretation of the data. PHD edited the table and figures. $\mathrm{CVH}$ edited the final version of the manuscript. All the authors have read the manuscript and contributed equally. All authors approved the final version.

\section{Funding}

This study was supported by a research grant from the Faculty of Medicine Universitas Airlangga, Surabaya, Indonesia. The Faculty of Medicine, Universitas Airlangga, Surabaya, Indonesia as the funder was responsible only to provide financial assistance and didn't interfere with technical aspects of the research. The whole process of this research are entirely not the responsibility of the funder.

\section{Availability of data and materials}

The datasets used and/or analysed during the current study available as a supplementary file.

\section{Ethics approval and consent to participate}

We sought an approval of whole project from Dr. Soetomo General Hospital as our Institutional Review Board. Ethical Clearance by Ethical Committee in Health Research Dr. Soetomo General Hospital Surabaya Number 390/Panke.KKE/ V/2017. The need to ask Ethical approval and the need to ask consent from parents was waived by our Ethical Committee because no human subjects were involved in this study.

\section{Consent for publication}

Not applicable.

\section{Competing interests}

The authors declare that they have no competing interests.

\section{Author details}

'Department of Pediatrics, Dr. Soetomo General Hospital, Faculty of Medicine Universitas Airlangga, Surabaya, Indonesia. ${ }^{2}$ Department of Pediatrics, Beatrix Children's Hospital, University Medical Center Groningen, University of Groningen, Groningen, the Netherlands.

Received: 13 June 2018 Accepted: 22 May 2019

Published online: 08 June 2019

\section{References}

1. Burke BL, Robbins JM, Bird TM, Hobbs CA, Nesmith C, Tilford JM. Trends in hospitalizations for neonatal jaundice and kernicterus in the United States, 1988-2005. Pediatrics. 2009;123(2):524-32.

2. Le Pichon JB, Riordan SM, Watchko J, Shapiro SM. The neurological sequelae of neonatal hyperbilirubinemia: definitions, diagnosis and treatment of the kernicterus Spectrum disorders (KSDs). Curr Pediatr Rev. 2017;13(3):199-209.

3. Greco C, Arnolda G, Boo NY, Iskander IF, Okolo AA, Rohsiswatmo R, et al. Neonatal jaundice in low- and middle-income countries: lessons and future directions from the 2015 Don Ostrow Trieste yellow retreat. Neonatology. 2016;110(3):172-80.
4. American Academy of Pediatrics Subcommittee on $\mathrm{H}$. Management of hyperbilirubinemia in the newborn infant 35 or more weeks of gestation. Pediatrics. 2004;114(1):297-316.

5. National Collaborating Centre for Women's and Children's Health (UK). Neonatal Jaundice. London: RCOG Press; 2010.

6. Dijk PH, de Vries TW, de Beer JJ, Dutch Pediatric A. Guideline 'Prevention, diagnosis and treatment of hyperbilirubinemia in the neonate with a gestational age of 35 or more weeks. Ned Tijdschr Geneeskd. 2009;153:A93.

7. Scheidt PC, Bryla DA, Nelson KB, Hirtz DG, Hoffman HJ. Phototherapy for neonatal hyperbilirubinemia: six-year follow-up of the National Institute of Child Health and Human Development clinical trial. Pediatrics. 1990;85(4):455-63.

8. Maisels MJ, McDonagh AF. Phototherapy for neonatal jaundice. N Engl J Med. 2008;358(9):920-8.

9. van Imhoff DE, Hulzebos CV, van der Heide M, van den Belt WW, Vreman HJ, Dijk $\mathrm{PH}$, et al. High variability and low irradiance of phototherapy devices in Dutch NICUs. Arch Dis Child Fetal Neonatal Ed. 2013;98(2):F112-6.

10. Cline BK, Vreman HJ, Faber K, Lou H, Donaldson KM, Amuabunosi E, et al. Phototherapy device effectiveness in Nigeria: irradiance assessment and potential for improvement. J Trop Pediatr. 2013:59(4):321-5.

11. Satrom K, Slusher T, Satrom J. Effectiveness of phototherapy units in Cameroon. J Trop Pediatr. 2014;60(3):264-6.

12. Jangaard KA, Vincer MJ, Allen AC. A randomized trial of aggressive versus conservative phototherapy for hyperbilirubinemia in infants weighing less than $1500 \mathrm{~g}$ : short- and long-term outcomes. Paediatr Child Health. 2007;12(10):853-8.

13. Morris BH, Oh W, Tyson JE, Stevenson DK, Phelps DL, O'Shea TM, et al. Aggressive vs. conservative phototherapy for infants with extremely low birth weight. N Engl J Med. 2008;359(18):1885-96.

14. Binabakti Niaga Perkasa. Fanem Phototherapy Bilitron 3006 BTI (use with infant incubator), KEMENKES RI AKL 20902504470, Brazil. https://e-katalog. Ikpp.go.id/backend/katalog/lihat_produk/83057. Accessed 21 Nov 2017.

15. Tesena Inovindo. Infant phototherapy unit. TLC $2 \mathrm{H}$ instruction for use rev 01, Jakarta Timur 13750, Indonesia http://aspak.yankes.kemkes.go.id/ beranda/wp-content/uploads/downloads/2014/09/Manual-INFANTPHOTOTHERAPY-UNITTLC-2H.pdf. Accessed 21 Nov 2017.

16. Ningbo David Medical Device. Neonate bilirubin phototherapy: XHZ-90L Jinghua Rd, high-tech industrial development zone, Ningbo China http:// www.kwadubemedical.co.za/XHZ90 Brochure.pdf. Accessed 21 Nov 2017.

17. Medical Devices Agency: Neonatal Phototherapy. Medela Phototherapy Lamp. MDA Evaluation 01161, London, GB, December 2001. http://www. wales.nhs.uk/sites3/Documents/443/ 01161\%20Medela\%20Phototherapy\%20Lamp.pdf. Accessed 21 Nov 2017.

18. Ohmeda. Halogen Phototherapy Light II Operation and Maintenance Manual. Ohmeda 9065, Guilford Road, Columbia, USA. http://www. frankshospitalworkshop.com/equipment/documents/light/user_manuals/ Ohmeda\%20Halogen\%20Phototherapy\%20Light\%20I\%20\%20User\%20manual.pdf. Accessed 21 Nov 2017.

19. Medical Devices Agency: Neonatal Phototherapy. Draeger PT 4000 Unit. MDA Evaluation 01162, London, GB, December 2001. http://www.wales.nhs.uk/ sites3/Documents/443/01162\%20Draeger\%20Phototherapy\%204000\%20Unit. pdf. Accessed 21 Nov 2017.

20. General Electric Company. Lullaby Phototherapy System. GE Healthcare 8880, Gorman Road Laurel, MD 20723, USA, 2008. http://www. bnicardcenter.co.id/corporatesite/files/ae/ae604634-fd5a-4b49-85e57771921c1e78.pdf. Accessed 21 Nov 2017.

21. Biostos: Phototherapy. BT-400 is ultimate solution for Neonatal Jaundice DaeRyung Techno Town, 448, Seoul, Korea. http://www.wtec.pt/demo/ bistos/BT-400.pdf. Accessed 21 Nov 2017.

22. General Electric Company. Lullaby LED Phototherapy System. GE Healthcare 8880, Gorman Road Laurel, MD 20723, USA, 2011. http://www.usmed-equip. com/content/datasheet/GE\%20lullaby-led-phototherapysystem\%20\%281\%29.pdf. Accessed 21 Nov 2017.

23. TENDE Technology and Development. Tende CareBlue LPT-240-2. Hacettepe Ivedek OSB Teknokenti 1368, Yenimahalle 06378, Akara/Turkey. http://phoenixneomed.com/wp-content/uploads/2017/02/Tende-CareBlueLPT-240-Brochure.pdf. Accessed 21 Nov 2017.

24. Novos Bilisphere Novos Tıbbi Cihazlar San. Tic. İth. ve İhr. Ltd.Şti Novos Bilisphere 360. Uzay Çağı Caddesi Ayık Iş Merkezi No: 82/B5 06374 Ostim, Ankara, Turkey https://kauppa.pedihealth.fi/attachment/ download/9372be1a08d3813c99a60066100f7dcf?inline=1. Accessed 21 Nov 2017. 
25. Vandborg PK, Hansen BM, Greisen G, Ebbesen F. Dose-response relationship of phototherapy for hyperbilirubinemia. Pediatrics. 2012;130(2):e352-7.

26. Donneborg ML, Vandborg PK, Hansen BM, Rodrigo-Domingo M, Ebbesen F. Double versus single intensive phototherapy with LEDs in treatment of neonatal hyperbilirubinemia. J Perinatol: official journal of the California Perinatal Association. 2018;38(2):154-8.

27. Bhutani VK, Cline BK, Donaldson KM, Vreman HJ. The need to implement effective phototherapy in resource-constrained settings. Semin Perinatol. 2011;35(3):192-7.

28. Hulzebos CV, Van't Klooster SJ, Lorenz K, Vreman HJ, Dijk PH. Irradiance levels of phototherapy devices: a national study in Dutch neonatal intensive care units. J Perinatol: official journal of the California Perinatal Association. 2017;37(7):839-42.

29. Olusanya BO, Osibanjo FB, Emokpae AA, Slusher TM. Irradiance decay in fluorescent and light-emitting diode-based phototheraphy devices: a pilot study. J Trop Pediatr. 2016;62(5):421-4.

30. Olusanya BO, Ogunlesi TA, Kumar P, Boo NY, Iskander IF, de Almeida MF, Vaucher YE, Slusher TM. Management of late-preterm and term infants with hyperbilirubinaemia in resource-constrained settings. BMC Pediatr. 2015;15:39.

31. Mesbah-Namin SA, Shahidi M, Nakhshab M. An increased genotoxic risk in lymphocytes from phototherapy-treated Hyperbilirubinemic neonates. Iran Biomed J. 2017:21(3):182-9.

32. Ramy N, Ghany EA, Alsharany W, Nada A, Darwish RK, Rabie WA, et al. Jaundice, phototherapy and DNA damage in full-term neonates. J Perinatol: official journal of the California Perinatal Association. 2016;36(2):132-6.

33. Yahia S, Shabaan AE, Gouida M, El-Ghanam D, Eldegla H, El-Bakary A, et al. Influence of hyperbilirubinemia and phototherapy on markers of genotoxicity and apoptosis in full-term infants. Eur J Pediatr. 2015;174(4):459-64.

34. Wickremasinghe AC, Kuzniewicz MW, Grimes BA, McCulloch CE, Newman TB. Neonatal phototherapy and infantile Cancer. Pediatrics. 2016;137:6.

35. Eggert P, Stick C, Schroder H. On the distribution of irradiation intensity in phototherapy. Measurements of effective irradiance in an incubator. Eur J Pediatr. 1984:142(1):58-61.

36. Eggert $P$, Stick $C$, Swalve $S$. On the efficacy of various irradiation regimens in phototherapy of neonatal hyperbilirubinaemia. Eur J Pediatr. 1988:147(5):525-8.

37. Djokomuljanto S, Quah BS, Surini Y, Noraida R, Ismail NZ, Hansen TW, et al. Efficacy of phototherapy for neonatal jaundice is increased by the use of low-cost white reflecting curtains. Arch Dis Child Fetal Neonatal Ed. 2006;91(6):F439-42.

38. Sivanandan S, Chawla D, Misra S, Agarwal R, Deorari AK. Effect of sling application on efficacy of phototherapy in healthy term neonates with nonhemolytic jaundice: a randomized conrolled trial. Indian Pediatr. 2009;46(1):23-8.

39. Sampurna MTA, Ratnasari KA, Etika R, Hulzebos CV, Dijk PH, Bos AF, et al. Adherence to hyperbilirubinemia guidelines by midwives, general practitioners, and pediatricians in Indonesia. PLoS One. 2018;13(4):e0196076.

40. Bhutani VK, Committee on F, Newborn, American Academy of Pediatrics. Phototherapy to prevent severe neonatal hyperbilirubinemia in the newborn infant 35 or more weeks of gestation. Pediatrics. 2011; 128(4):e1046-52.

\section{Publisher's Note}

Springer Nature remains neutral with regard to jurisdictional claims in published maps and institutional affiliations.

Ready to submit your research? Choose BMC and benefit from:
- fast, convenient online submission
- thorough peer review by experienced researchers in your field
- rapid publication on acceptance
- support for research data, including large and complex data types
- gold Open Access which fosters wider collaboration and increased citations
- maximum visibility for your research: over 100M website views per year
At BMC, research is always in progress.
Learn more biomedcentral.com/submissions

